\title{
Measurement of fungicide efficacy on post-harvest diseases: wound anthracnose, quiescent anthracnose, crown rot
}

\author{
Luc de Lapeyre de Bellaire ${ }^{1 *}$, Marc Chillet $^{2}$, Yolande Chilin-Charles ${ }^{3}$
}

${ }^{1}$ CIRAD, UPR Syst., Banan. Ananas, CARBAP, BP 832, Douala, Cameroon

luc.de_lapeyre@cirad.fr,

2 CIRAD, UMR Qualisud, Fac. Farm. Univ. de Sao Paulo, avenida Lineu Prestes, 580, Bloco 14 05508-900n Sao Paulo, SP, Brasil

marc.chillet@cirad.fr

${ }^{3}$ CIRAD, UPR Mult. Vég., Stn. de Neufchâteau, 97130 ,

Capesterre Belle-Eau,

Guadeloupe, France

yolande.chilin-charles@cirad.fr

\section{Measurement of fungicide efficacy on post-harvest diseases: wound anthracnose, quiescent anthracnose, crown rot.}

\begin{abstract}
Introduction. This protocol aims at evaluating (a) the efficacy of new fungicides for the control of post-harvest diseases, (b) the efficacy of various application methods for the chemical control of post-harvest diseases, and (c) the quality of the fungicide solution during the same packing day where this solution is recycled. The principle, key advantages, starting plant material, time required and expected results are presented. Materials and methods. Materials required and details of the eighteen steps of the protocol (fruit sampling and inoculum preparation, wound anthracnose study, quiescent anthracnose study, and crown-rot study) are described. Results. Comparison between untreated control bananas and bananas treated with fungicide allows the calculation of the fungicide treatment efficacy.
\end{abstract}

France (Guadeloupe) / Musa sp. / post-harvest control / efficacy / fungicides / methods

Mesure de l'efficacité d'un fongicide sur les maladies de conservation : anthracnose de blessure, anthracnose quiescente, pourriture de la couronne.

Résumé - Introduction. Ce protocole vise à évaluer (a) l'efficacité de nouveaux fongicides pour le contrôle des maladies de conservation, (b) l'efficacité de diverses méthodes d'application pour la lutte chimique contre ces mêmes maladies, (c) la qualité de la solution fongique au cours d'un même jour de conditionnement pendant lequel cette solution est réutilisée. Le principe, les principaux avantages, le matériel végétal de départ, le temps nécessaire et les résultats attendus de la méthode sont présentés. Matériel et méthodes. Le matériel nécessaire et le détail des dix-huit étapes du protocole (prélèvement de fruits et préparation d'inoculum, étude de l'anthracnose de blessure, étude de l'anthracnose quiescente et étude de la pourriture de couronne) sont décrits. Résultats. La comparaison entre les bananes témoins non traitées et les bananes traitées avec un fongicide permet de calculer l'efficacité du fongicide.

France (Guadeloupe) / Musa sp. / lutte après récolte / efficacité / fongicide / méthode

\section{Introduction}

Fruits, 2008, vol. 63, p. 303-306 (C) 2008 Cirad/EDP Sciences All rights reserved DOI: 10.1051/fruits:2008027 www.fruits-journal.org

\section{Application}

This protocol aims at evaluating:

- the efficacy of new fungicides for the control of post-harvest diseases,
- the efficacy of various application methods for the chemical control of post-harvest diseases,

- the quality of the fungicide solution during the same packing day where this solution is recycled (the fungicide solution might be diluted or altered by the latex). 


\section{Principle}

Banana fruits are infected through artificial inoculation of the pathogens involved in post-harvest diseases. The fungicide treatment is realised after the inoculation. Fungicide efficacy is measured as the percentage of reduction of the disease in comparison with an untreated control [1].

\section{Key advantages}

- The method is precise and reliable.

- It simulates the conditions of industrial exportation of bananas and it is particularly adapted to this situation. However, the described method is more time-consuming than the observation of natural infections.

\section{Starting material}

The method requires mature, freshly harvested bananas and fungal cultures of $\mathrm{Col}$ letotrichum musae.

\section{Time estimation}

For wound anthracnose, the time required for two treatments (control and treated fruits) is $30 \mathrm{~min}$ for fruit sampling; $45 \mathrm{~min}$ for fruit inoculation; $30 \mathrm{~min}$ for fruit wounding; $20 \mathrm{~min}$ for disease assessment.

For quiescent anthracnose, the time required for two treatments (control and treated fruits) is $30 \mathrm{~min}$ for fruit sampling; $45 \mathrm{~min}$ for fruit inoculation; $20 \mathrm{~min}$ for disease assessment.

For crown rot, the time required for two treatments (control and treated fruits) is $30 \mathrm{~min}$ for fruit sampling; $45 \mathrm{~min}$ for fruit inoculation; $30 \mathrm{~min}$ for disease assessment.

\section{Expected results}

The method makes it possible to determine the percentage of lesion reduction between treated and control bananas after the fungicide treatment. Control banana corresponds to inoculated bananas which were not treated with the fungicide.

\section{Materials and methods}

\subsection{Laboratory materials}

The protocol requires:

- agar plates with Mathur's medium $\left(\mathrm{MgSO}_{4}\right.$ $7 \mathrm{H}_{2} \mathrm{O} 2.5 \mathrm{~g}$; peptone $1 \mathrm{~g}$; yeast extract $1 \mathrm{~g}$; saccharine $10 \mathrm{~g}$; agar $15 \mathrm{~g}$; water $1 \mathrm{~L}$ ), or PDA medium,

- a Malassez counting cell,

- sterile distilled water,

- a microscope,

$-50 \%$ alcohol,

- a computerised penetrometer with a rounded probe (1-cm diameter),

- a controlled environment cabinet regulated at $13{ }^{\circ} \mathrm{C}$,

- a controlled environment cabinet regulated at $20{ }^{\circ} \mathrm{C}$,

- a controlled environment cabinet regulated at $25^{\circ} \mathrm{C}$,

- a ripening room regulated at $20{ }^{\circ} \mathrm{C}$ or an airtight ripening tank stored in a controlled temperature chamber regulated at $20{ }^{\circ} \mathrm{C}$,

- ethylene, e.g., a bottle of azethyl (95\% nitrogen $+5 \%$ ethylene)

\subsection{Protocols}

\section{Fruit sampling and inoculum} preparation

- Step 1. Fruit sampling

For each treatment, sample in the packing station 20 banana hands (in position 3 from the top of the bunch) from 20 bunches. If the amount of fruit collected is not sufficient for the experiment, hand 2 of each bunch will be collected as well. Each hand (or group of two hands) coming from one bunch will be considered as a block for statistical analysis by ANOVA.

For each treatment, a cluster of four bananas will be collected on each bunch, so the same treatment is carried over a group of 20 clusters.

Note: all experiments include at least three treatments: an untreated control (inoculated bananas untreated with the fungicide), a reference fungicide treatment (thiabendazole $4-5 \mathrm{~g} \cdot \mathrm{L}^{-1}$; example of fungicide Mertect $20 \mathrm{~S}$ at $220 \mathrm{~g} \cdot \mathrm{L}^{-1}$ a.i.), and the test treatment 
(inoculated bananas treated with the fungicide).

- Step 2. Inoculum preparation

- Inoculate Mathur's medium plates with a small plug from a fungal colony of Colletotrichum musae. Note: fungal cultures should be monosporic and not sub-cultured more than five times (initiate new cultures from frozen conidial suspensions at $-80{ }^{\circ} \mathrm{C}$ in glycerine 30\%). The C. musae strain used should be susceptible to the fungicides used for the experiment.

- Store fungal cultures at $25^{\circ} \mathrm{C}$ for $10 \mathrm{~d}$.

- Flow the fungal cultures with distilled sterile water.

- Filtrate the conidial suspension through a 35- $\mu \mathrm{m}$ sieve.

- Calibrate the conidial suspension to $\left(10^{6}\right.$ and $\left.10^{4}\right)$ conidia $\cdot \mathrm{mL}^{-1}$ with the Malassez counting cell.

\section{Wound anthracnose study}

\section{- Step 3}

Inoculate two fruits both on the external and on the internal row of the cluster, on the side face (use two bananas located at the same edge of the cluster). Deposit a $25-\mu \mathrm{L}$ droplet of the Colletotricum musae conidial suspension calibrated to $10^{6}$ conidia $\cdot \mathrm{mL}^{-1}$ (locate inoculation area) in the centre of the side face.

\section{- Step 4}

Once the droplet is evaporated, cover the inoculated area with a humidified swab and wrap with plastic to maintain humidity. Store the fruits at $25-27^{\circ} \mathrm{C}$ for $24 \mathrm{~h}$.

\section{- Step 5}

Bruise the fruit at the place where inoculum was deposited. Crushing is done with a computerised penetrometer equipped with a rounded probe. The speed of the probe is $5 \mathrm{~mm} \cdot \mathrm{s}^{-1}$ and a $5-\mathrm{mm}$ compression is exerted on the fruit for $4 \mathrm{~s}$.

\section{- Step 6}

Carry out the fungicide treatment. Untreated control: fruits are dipped in or sprayed with water; reference fungicide treatment: fruits are dipped for $1 \mathrm{~min}$ in a thiabendazole solution $\left(4.4 \mathrm{~g} \cdot \mathrm{L}^{-1}\right)$; test fungicide: fruits are dipped in or sprayed with the fungicide solution.

Note: the fungicide solutions should be prepared the day of treatment. Three parameters must be defined for the fungicide treatment: (a) the fungicide concentration, which should be determined accurately, (b) the duration of the treatment, (c) the type of application: dipping or spraying (outflow, type of nozzle).

- Step 7

Pack the 20 clusters of the same treatment in a standard box, in a perforated polybag. Store fruits at $13^{\circ} \mathrm{C}$.

- Step 8

Ten days after inoculation, start measuring the surface of the lesions [length $\times$ width $\times$ $(\pi / 4)]$ and repeat the measurement every $2-$ $3 \mathrm{~d}$ until fruits are ripe.

- Step 9

Calculate the average of surface lesions for the untreated control (SLC) and for the fungicide-treated fruits (SLT). Compare these data through ANOVA, each bunch being considered as a block.

- Step 10

Calculate the fungicide treatment efficacy (FE) as $\mathrm{FE}=[1-(\mathrm{SLC} / \mathrm{SLT})] \times 100$.

\section{Quiescent anthracnose study}

- Step 11

For quiescent anthracnose study, proceed exactly as described for wound anthracnose study, except for step 5 which is not necessary.

\section{Crown-rot study}

- Step 12

For each cluster, remove a thin slice of crown on all sections and sterilise the crown in $50 \%$ ethanol.

- Step 13

Once the crown surface is dry, deposit $50 \mu \mathrm{L}$ of the conidial suspension, calibrated to $10^{4}$ conidia $\cdot \mathrm{mL}^{-1}$, on the upper face of the crown. Cover this droplet with a $5-\mathrm{mm}$ paper disk and place the fruits at $25^{\circ} \mathrm{C}$ for $3 \mathrm{~h}$. 


\author{
- Step 14 \\ Carry out the fungicide treatment as previ- \\ ously described (steps 6 and 7).
}

- Step 15

Ten days after inoculation, make an external evaluation of crown rot (ECR) according to the following rot scale: 0: no crown-rot lesion; 1 : less than $25 \%$ of the crown surface is rotten; $2: 25-50 \%$ of the crown surface is rotten; 3: 50-75\% of the crown surface is rotten; 4 : more than $75 \%$ of the crown surface is rotten.

Note: this evaluation corresponds to the evaluation that is made at the entrance of the ripening room where most controls of quality are realised.

- Step 16

Calculate the average of ECR for the untreated control $\left(\mathrm{ECR}_{\mathrm{Control}}\right)$, for the reference fungicide $\left(\mathrm{ERC}_{\text {reference }}\right)$ and for the fungicide-treated fruits $\left(\mathrm{ECR}_{\text {fungicide }}\right)$. Calculate the fungicide treatment efficacy (FE) as $\mathrm{FE}=\left[1-\left(\mathrm{ECR}_{\text {control }} / \mathrm{ECR}_{\text {fungicide }}\right)\right] \times 100$.

\section{- Step 17}

Introduce fruits into a ripening room regulated at $20{ }^{\circ} \mathrm{C}$ or into an airtight ripening tank stored in a controlled temperature chamber regulated at $20^{\circ} \mathrm{C}$. Inject ethylene gas at a concentration of $1000 \mu \mathrm{L} \cdot \mathrm{L}^{-1}$.

- Step 18

$24 \mathrm{~h}$ after the ethylene treatment, remove ethylene by aeration of the chamber and store the fruits at $20^{\circ} \mathrm{C}$ for another $2 \mathrm{~d}$.

After the $3 \mathrm{~d}$ of storage, make an internal evaluation of crown rot. Separate the cluster

Figure 1.

Comparison between untreated control bananas and bananas treated with fungicide which allows the calculation of the fungicide treatment efficacy. into two and measure the length (L) and width (W) of the internal rot. Internal rot surface (IRS) is then calculated as IRS $=\mathrm{L} \times \mathrm{W}$. This evaluation corresponds to the evaluation that is made at the exit of the ripening room. Calculate the average of IRS for the untreated control $\left(\mathrm{ICR}_{\mathrm{control}}\right)$, for the reference fungicide $\left(\mathrm{IRS}_{\text {reference }}\right)$ and for the fungicide-treated fruits $\left(\mathrm{ICR}_{\text {fungicide }}\right)$. Compare these data through ANOVA, each bunch being considered as a block. Calculate the fungicide treatment efficacy $(\mathrm{FE})$ as $\mathrm{FE}=[1-$ $\left.\left(\mathrm{ICR}_{\text {control }} / \mathrm{ICR}_{\text {fungicide }}\right)\right] \times 100$.

\subsection{Troubleshooting}

If very few lesions are observed on the untreated control, two explanations can be advanced:

(a) Fungal cultures were sub-cultured too much and the C. musae strains lost their pathogenicity. Solution: initiate new fungal cultures from frozen conidial suspensions.

(b) Fruits were dried after the inoculation (especially for anthracnose). Solution: maintain high humidity after the inoculation (cover with a wet swab and wrap the fruit with plastic; maintain a high humidity in the room).

\section{Typical results obtained}

Comparison between untreated control bananas and bananas treated with fungicide (figure 1) allows the calculation of the fungicide treatment efficacy.

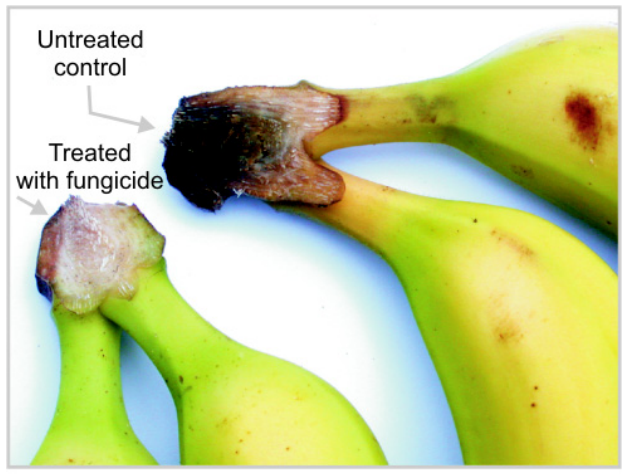

\section{References}

[1] Garbay M., de Lapeyre de Bellaire L. Méthode d'étude de l'efficacité pratique des préparations fongicides destinées à lutter contre les maladies de conservation des bananes, Méthode CEB (Comm. Essais Biol.) $n^{\circ} 233$, ANPP (ed.), CD-rom janvier 2005. 